\title{
Characterization of Synthetic Ni(II)-Xylenol Complex as a Photosensitizer for Wide-Band Gap ZnO Semiconductor Electrodes
}

\author{
Suman Kushwaha and Lal Bahadur \\ Department of Chemistry, Faculty of Science, Banaras Hindu University, Varanasi 221005, India \\ Correspondence should be addressed to Suman Kushwaha, kushwaha.suman@gmail.com
}

Received 22 November 2010; Accepted 2 February 2011

Academic Editor: Vincenzo Augugliaro

Copyright ( 2011 S. Kushwaha and L. Bahadur. This is an open access article distributed under the Creative Commons Attribution License, which permits unrestricted use, distribution, and reproduction in any medium, provided the original work is properly cited.

A synthetic $\mathrm{Ni}^{\mathrm{II}} \mathrm{L}\left(\mathrm{H}_{2} \mathrm{O}\right)_{2}$ complex ( $\mathrm{L}=$ xylenol orange, 3,3'-bis [N,N-di(carboxymethyl)-aminomethyl]-o-cresol sulphonapthalein $\left.\left(\mathrm{H}_{2} \mathrm{O}\right)_{2}\right)$, which is a water-soluble dye, has been studied for its photosensitizing properties at $n$-ZnO semiconductor electrodes prepared by sol-gel techniques. The absorption spectrum of aqueous solution of this complex exhibits a strong peak at $563 \mathrm{~nm}$ and a shoulder at $526 \mathrm{~nm}$ wavelength of light. The sandwich-type dye-sensitized solar cell using $\mathrm{ZnO}$ semiconducting thin film with test dye anchored onto it showed the cell output as follows: $V_{\mathrm{OC}}=0.506 \mathrm{~V}, J_{\mathrm{sc}}=1.68 \mathrm{~mA} \mathrm{~cm}^{-2}$, and FF $=0.41$ under illumination with full spectrum of light (intensity $\left.520 \mathrm{~mW} \mathrm{~cm}^{-2}\right)$, while on illumination with visible light $\left(\lambda>420 \mathrm{~nm}\right.$, intensity $\left.480 \mathrm{~mW} \mathrm{~cm}^{-2}\right)$, $V_{\mathrm{OC}}=0.506 \mathrm{~V}, J_{\mathrm{sc}}=1.4 \mathrm{~mA} \mathrm{~cm}{ }^{-2}$, and $\mathrm{FF}=0.49$ were achieved. Maximum incident photon-to-current conversion efficiency for the present system was found to be $8.7 \%$ at wavelength $\left(\lambda_{\max }=563 \mathrm{~nm}\right)$.

\section{Introduction}

Dye-sensitized solar cells (DSSCs) are unique and attractive devices for the conversion of solar energy into electricity based on sensitization of wide band gap semiconductors [114]. In general in DSSCs dye molecules adsorbed on the surface of nanocrystalline $\mathrm{ZnO}$ are photoexcited by incident light and inject electrons into the conducting band of $\mathrm{ZnO}$. The oxidized dye is regenerated by the reduced species of the redox-couple, typically $\mathrm{I}^{-} / \mathrm{I}_{3}{ }^{-}$, dissolved in the electrolyte. The resulting $\mathrm{I}_{3}{ }^{-}$diffuses to the Pt-counter electrode, where it is reduced. Since dye plays an important role in absorbing visible light and transferring photon energy into electricity, much attention has been paid to survey the effective sensitizer dyes. It is necessary for sensitizer dyes to have suitable energy levels to transfer electrons and anchor group(s) to have affinity for semiconductors. Usually, synthetic inorganic compounds such as ruthenium (II) complexes with carboxylated polypyridyl ligands are employed as molecular sensitizers (S) in DSSCs due to their intense charge-transfer absorption in the whole visible range of solar spectrum, excellent stability, and highly efficient metal-to-ligand charge transfer [15-17]. The energies of the MLCT states can be altered systematically by modifying the anchoring ligands as well as by changing the ancillary ligands or its substituents. The wide possibilities to tune the MLCT energy led to the preparation of many different compounds that have been investigated for semiconductor sensitization. In order to replace the rare and expensive ruthenium compounds, many kinds of organic synthetic dyes have been actively studied and tested as low-cost materials [18-27]. This work is in continuation of this series of investigations in which a newly synthesized transition metal complex $\mathrm{Na}_{4}\left[\mathrm{NiL}\left(\mathrm{H}_{2} \mathrm{O}\right)_{2}\right]$, where $\mathrm{L}$ is 3,3 bis[N,N-di(carboxymethyl)-aminomethyl]-o-cresol sulphonphthalein ligand [28] has been characterized for its photosensitizing properties at $\mathrm{n}-\mathrm{ZnO}$ thin-film electrodes prepared by sol-gel method. The results of this investigation are reported here.

\section{Experimental}

2.1. Materials and Equipments. LiI (Aldrich), iodine (CDH, India) were used as redox couple. Ethanol (Merck, India) was dried following the method of Lund and Bjerrum [29] 
before using it for preparing $\mathrm{ZnO}$-sol. Zinc acetate $(\mathrm{CDH}$, India) and $\mathrm{LiOH} \cdot \mathrm{H}_{2} \mathrm{O}$ (Alfa product) were used as received. The platinum catalyst (T/SP) was obtained from Solaronix for counter electrode. The sealing agent (SX1170-60, $50 \mu \mathrm{m}$ ) was obtained from Solaronix. The Nickel (II)-xylenol orange metal complex studied as a photosensitizer was synthesized by Pandey and Narang [28] and made available to us for investigation.

$\mathrm{X}$-ray diffraction pattern of $\mathrm{ZnO}$ powder was obtained with X-ray diffractometer (Model 3000, SEIFERT, Germany) using $\mathrm{CuK} \alpha$ radiation of $1.54 \AA$ to determine the crystal structure. Current and voltage of XRD were maintained at $30 \mathrm{~mA}$ and $40 \mathrm{kV}$ during the measurement. The XRD pattern was recorded in $2 \theta$ range. Morphology of $\mathrm{ZnO}$ thin film was examined by scanning electron microscope (FESEM, quanta $200 \mathrm{FEG}$ ). Voltammograms were recorded using a three-electrode cell consisting of $\mathrm{Ag} / \mathrm{Ag}^{+}$reference electrode $\left(0.1 \mathrm{AgNO}_{3}+0.01 \mathrm{TBAP}\right.$ in acetonitrile medium), Pt wire auxiliary electrode and $\mathrm{Pt}$ disc working electrode. $\mathrm{NaClO}_{4}(0.1 \mathrm{M}$ in water) was used as supporting electrolyte. Experimental solution was purged with $\mathrm{N}_{2}$ gas for $30 \mathrm{~min}$ before recording the voltammograms.

Electrochemical measurements were made with the help of a bipotentiostat (model no. AFRDE4E, Pine Instrument Company, USA) and a computer controlled e-corder (model no. 201, e-DAQ, Australia). A $150 \mathrm{~W}$ xenon arc lamp with lamp housing (model no. 66057) and power supply (model no. 68752), all from Oriel Corporation, USA, was used as a light source. The semiconductor electrode was illuminated after passing the collimated light beam through a 6 inch long water column (to filter IR radiation) and condensing it with the help of fused silica lenses (Oriel Corporation, USA). This IR-filtered light is referred to as "white light" in the text. Whenever required, the UV part of the white light was cut off by using a long pass filter (model no. 51280, Oriel Corporation, USA) and the resultant light $(\lambda>420 \mathrm{~nm})$ obtained this way is referred to as "visible light". The monochromatic light was obtained with the use of a monochromator (Oriel model 77250 equipped with model 7798 grating), and the corresponding photocurrent was measured with the help of a digital multimeter (Philips model no. 2525) in combination with the potentiostat. Light intensities were measured with a digital photometer (Tektronix model J16 with model J6502 sensor) in combination with neutral density filters (model no. 50490-50570, Oriel, USA). The absorption spectrum of the test dye $\mathrm{Ni}(\mathrm{II})$ xylenol complex was recorded on Cary 2390 (Varian) spectrophotometer.

2.2. Synthesis of Complexes. This water soluble metal complex was prepared by mixing aqueous solutions $(0.01 \mathrm{M})$ nickel (II), and the ligand, 3,30-bis[N,N-di(carboxymethyl)aminomethyl]-o-cresol sulphonphthalein $\left(\mathrm{Na}_{4} \mathrm{H}_{2} \mathrm{~L}\right)(0.01 \mathrm{M})$, in $1: 1$ ratio. The $\mathrm{pH}$ of the mixtures was raised to 11 by addition of $\mathrm{NaOH}$ solution and the mixture was refluxed on a water bath for $2 \mathrm{~h}$. After cooling the solution, $\mathrm{Me}_{2} \mathrm{CO}$ (ca $50 \mathrm{~cm}^{3}$ ) in $100 \mathrm{~cm}^{3}$ aqueous solution was added until shining microcrystals were formed. The metal (II) complex with $\mathrm{Na}_{4} \mathrm{H}_{2} \mathrm{~L}$ was analyzed for $\mathrm{M}, \mathrm{C}, \mathrm{H}, \mathrm{N}$, and $\mathrm{S}$ content. Detailed process of the synthesis, characterization, spectral and properties of metal complex have been given somewhere else [28].

2.3. Formation of $\mathrm{ZnO}$ Precursor Sol and Thin-Film Preparation. Thin films of $\mathrm{ZnO}$ of nanometer-sized colloidal $\mathrm{ZnO}$ were prepared following the method of Spanhel and Anderson [30]. In brief, the organometallic precursor was prepared by refluxing $0.1 \mathrm{M}$ zinc acetate solution in absolute ethanol (dry) for about $3 \mathrm{~h}$ at $80^{\circ} \mathrm{C}$ avoiding its exposure to moisture. Then, keeping it in ice-cold water, equimolar $\mathrm{LiOH} \cdot \mathrm{H}_{2} \mathrm{O}$ was added to it, and the hydrolysis was allowed to continue for half an hour keeping the container in an ultrasonicator. This resulted in a dense sol consisting of $\mathrm{ZnO}$ colloids and is coated on conducting glass substrate by dip coating. A portion of the colloidal sol was left to get dried, and this dried powder was sintered at $450^{\circ} \mathrm{C}$ for $\mathrm{X}$-ray crystallographic studies. Scheme 3 shows the method of preparation of $\mathrm{ZnO}$ sol and subsequently its thin film on conducting glass substrate. Prior to using it for film deposition, the substrate was washed with mildly heated, soapy pure water and then ultrasonically cleaned with acetone first and then with iso-propanol for $30 \mathrm{~min}$ each. It was further cleaned with ultra pure water for $15 \mathrm{~min}$ and kept in oven at $80^{\circ} \mathrm{C}$ for 30 minutes. A U-shaped frame of adhesive tape was put over the conducting face of the glass substrate to control the thickness of the $\mathrm{ZnO}$ film and to provide noncoated area for electrical contact. This process was repeated 5-6 times to get the films of the required thickness. The deposited films were air dried and then the adhesive tapes were carefully removed. These films were finally annealed in air at $450^{\circ} \mathrm{C}$ for $1.5 \mathrm{~h}$. This way $\mathrm{ZnO}$ thin film of approximately $2 \mu \mathrm{m}$ thickness was obtained.

2.4. Photoelectrochemical Measurements. For studying the performance of test dye on $\mathrm{ZnO}$ thin-film electrode sandwich type cells were fabricated. For this purpose, the thinfilm electrode was dipped into $0.1 \mathrm{mM}$ aqueous solution (deionized water) of test dye for overnight. The dye-coated film was air dried. This was used as photoelectrode in the cell. To provide space for filling cell electrolyte and to assemble the cell, the hot-melt sheet (SX1170-60, $50 \mu \mathrm{m}$ thick, Solaronix) was used as sealing frame. The counter electrode was prepared on FTO (Flexitec, Product no. 102-020, sheet resistance $10-20 \Omega / \square$ ) by screen printing method using platinum catalyst (T/SP, Solaronix) and then annealed at $450^{\circ} \mathrm{C}$ for 30 minutes. To assemble the cell, the counter electrode was put over the photoelectrode and sealed using spacer/sealing material and heating it at $\sim 80^{\circ} \mathrm{C}$. An electrolyte solution composed of $0.5 \mathrm{M} \mathrm{LiI}$ and $0.05 \mathrm{M} \mathrm{I}_{2}$ in propylene carbonate (PC) was introduced into the cell by capillary action and then sealed properly.

\section{Results and Discussion}

3.1. Structural Characterization of $Z n O$ Thin Film. The crystalline structure of the $\mathrm{ZnO}$ particles was analyzed through X-ray diffraction (XRD). The XRD of $\mathrm{ZnO}$ powder annealed at $450^{\circ} \mathrm{C}$ is shown in Figure 1 . The diffraction peaks of the sample reveals that $\mathrm{ZnO}$ crystallizes well after 


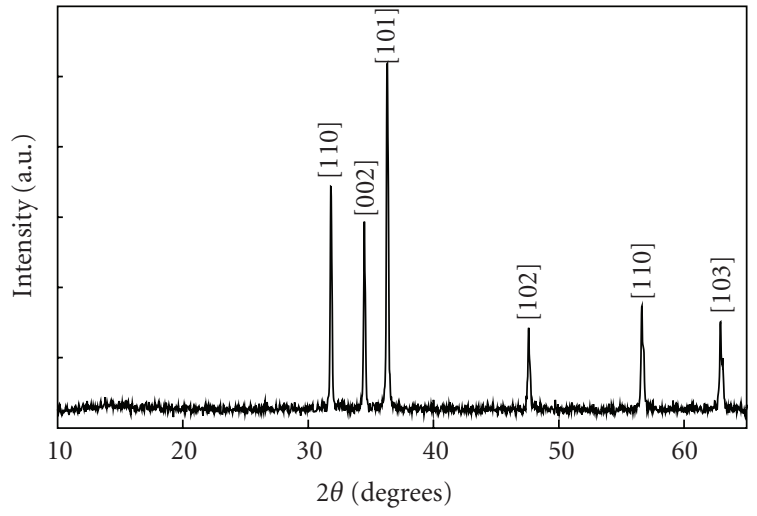

Figure 1: XRD of ZnO powder prepared by Spenhel and Anderson method and sintered at $450^{\circ} \mathrm{C}$.<smiles>[R2]OC(=O)CN(CC(=O)O[R2])CC1=CC(=C(c2cc(C)c(O)c(CN(CC(=O)O[R])CC(=O)O[R2])c2)c2ccccc2S(C)(=O)=O)C=C(C)C1=O</smiles>

SCHEme 1: Structure of ligand $\mathrm{Na}_{4} \mathrm{H}_{2} \mathrm{~L}$.

annealing. All the diffraction peaks are in agreement with the reported data in JCPDS Card no. 36-1451 for hexagonal wurtzite phase of zinc oxide. Average grain size has been calculated using Scherrer's equation

$$
d=\frac{0.9 \lambda}{B \cos \theta}
$$

where $\lambda, \theta$, and $B$ are the X-ray wavelength (1.54 $\AA$ ), Braggs diffraction angle, and full width at half maximum (FWHM), respectively. The calculated average size of zinc oxide nanoparticles was found to be $\sim 30-35 \mathrm{~nm}$, which is in agreements with that already reported using this method of sol preparation [31].

3.2. Surface Morphology. Figure 2 show the SEM image of $\mathrm{ZnO}$ thin film prepared by depositing the colloidal sol on conducting glass and annealed at $450^{\circ} \mathrm{C}$. The film shows a

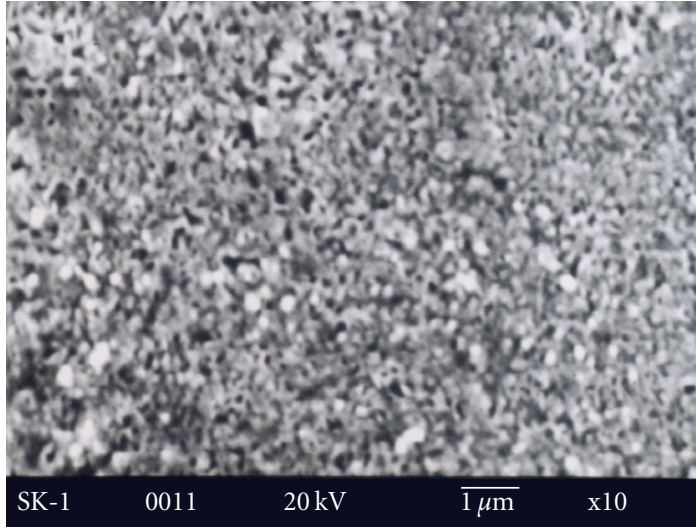

FIGURE 2: SEM image of the nanocrystalline thin film prepared by using zinc oxide colloidal sol (annealing conditions: at $450^{\circ} \mathrm{C}$ in air for $1.5 \mathrm{~h}$ ).

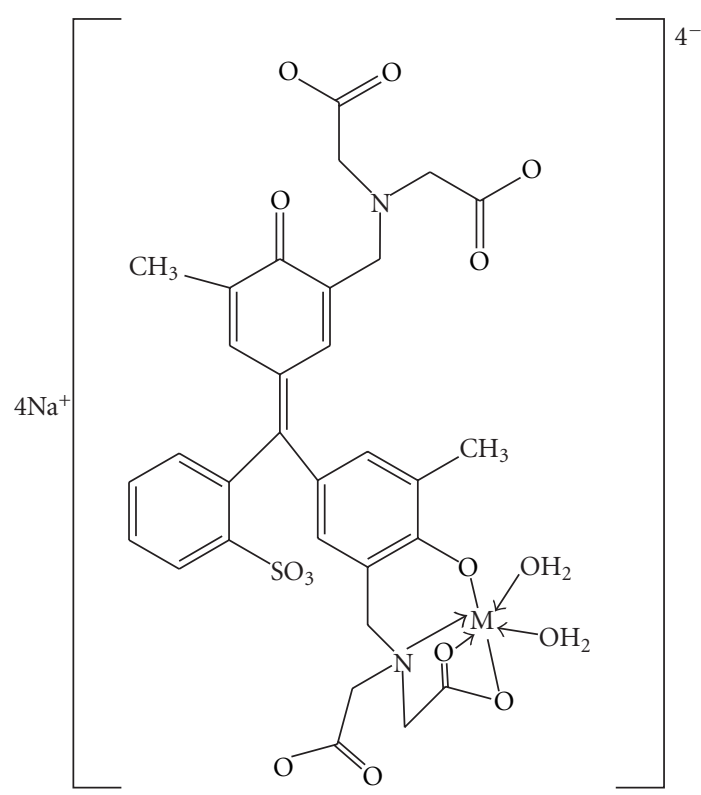

Scheme 2: Structure of nickel (II) metal complex with 3,30-bis[N,Ndi(carboxymethyl)-aminomethyl]-o-cresol sulphonphthalein ligand as proposed by Pandey and Narang [28].

smooth porous surface with a fine microstructure, without cracks or void.

\subsection{Characterization of Ni(II) Xylenol Metal Complex}

3.3.1. Structure of the Complex. Ligand $\mathrm{Na}_{4} \mathrm{H}_{2} \mathrm{~L}$ (Scheme 1) has several bonding sites, but the two acidic chelating groups on the side of its large sulphonphthalein nucleus may behave like branched donating sites enhancing the possibility of mononuclear or binuclear complex formation with metal ions. In binuclear complex formation, both sides of the sulphonphthalein nucleus are chelated by $\mathrm{PhO}^{-}, \mathrm{N}$, and two $\mathrm{COO}^{-}$electron pairs. Empirical formulae derived from analytical data $(\mathrm{C}, \mathrm{H}, \mathrm{N}, \mathrm{S}$, and metal contents) suggest the formation of $1: 1(\mathrm{M}: \mathrm{L})$ complexes. The assumption of $4: 1$ 

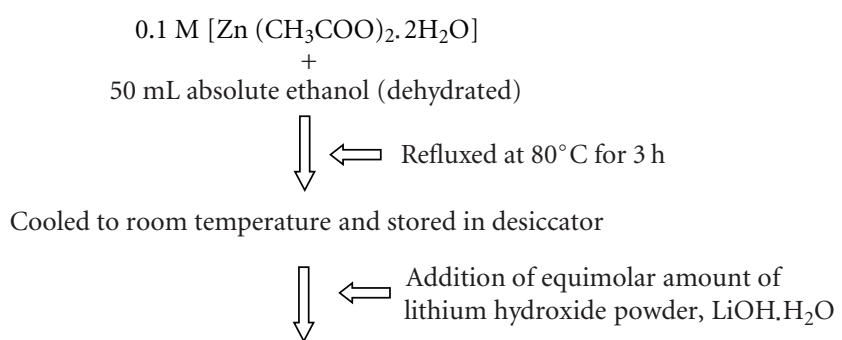

Kept in ultrasonicator for 5 mins

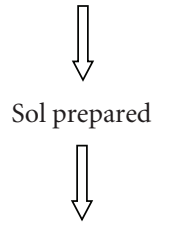

Dip coated on conducting glass substrate and air dried

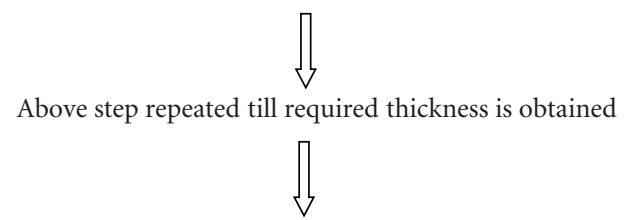

Sintered at $450^{\circ} \mathrm{C}$ for $1.5 \mathrm{~h}$<smiles>C=[W]</smiles>

Nanocrystalline $\mathrm{ZnO}$ thin film prepared

Scheme 3: Schematic presentation of preparation of $\mathrm{ZnO}$ sol and its thin film on conducting glass substrate.

complex electrolyte can be confirmed by high molar conductance values (greater than $400 \Omega^{-1} \mathrm{~cm}^{2} \mathrm{~mol}^{-1}$ ) observed in $1 \mathrm{mM}$ aqueous solution of the complex though the conductivity values are slightly lower than the value for unitetravalent electrolyte. The complex anion with $4^{-}$charge is voluminous and poorly mobile, considerably reducing its contribution to the molar conductivity [28]. Depending on $\mathrm{pH}$, the chelation process indicates stepwise formation of stable complex species namely $\mathrm{MH}_{2} \mathrm{~L}^{2-}, \mathrm{MHL}^{3-}$, and $\mathrm{ML}^{4-}$ in solution.

Scheme 2 represents the chemical structure of nickel (II) metal complexes with 3,30-bis[N,N-di(carboxymethyl)aminomethyl]-o-cresol sulphonphthalein ligand as proposed by Pandey and Narang [28].

\subsubsection{Redox Behaviour of Nickel (II) Xylenol Complex.} The cyclic voltammograms of xylenol nickel (II) complex in aqueous solution containing $0.1 \mathrm{M} \mathrm{NaClO}_{4}$ obtained in the potential range of $-1.5 \mathrm{~V}$ to $1.0 \mathrm{~V}$ at different scan rates $\left(0.020-0.200 \mathrm{~V} \mathrm{~s}^{-1}\right)$ are shown in Figure 3(a) while Figure 3(b) shows cyclic voltammograms (10 cycles) repeated at a fixed scan rate of $100 \mathrm{mV} / \mathrm{s}$. No measurable shift in peak has been observed which shows that the complex is stable in solution. From these curves it is evident that during forward scan in anodic potential range one peak (b) $\left(E_{p, a}=\right.$ $+0.420 \mathrm{~V}$ ) was observed. During the reverse scan cathodic peaks $(\mathrm{c})$ and $(\mathrm{d})$ were observed at $\left(E_{p, c}\right)_{c}=-0.112 \mathrm{~V}$ and
$\left(E_{p, c}\right)_{d}=-0.858 \mathrm{~V}$. The reoxidation anodic peak (a) $\left(E_{p, a}=\right.$ $-0.732 \mathrm{~V}$ ) seems to be associated with the cathodic peak (d) but (b) has no associated cathodic peak. It is pertinent to point out here that though peaks (d) and (a) have been assigned to reduction of $\mathrm{Ni}$ (II) in complex cation to $\mathrm{Ni}$ (I) and its reversal, their separation $\left(\left(E_{p, a}\right)_{a}-\left(E_{p, c}\right)_{c}\right)$ is quite large as compared to that expected for one electron transfer process and it is also not stable with the change in the scan rate from 20 to $200 \mathrm{mV} / \mathrm{s}$. However, it can be added here that the cathodic peak potential $\left(E_{p, c}=-0.858 \mathrm{~V}\right)$ corresponding to (d) matches closely with the reduction potential $E_{p, c}=-0.85 \mathrm{~V}$ reported by Bulut [32] for the same cation in another transition metal complex. $E_{p, c}$ shifting to more negative potentials (from -0.830 to $-0.858 \mathrm{~V}$ ) was observed when the scan rate was increased from 20 to $200 \mathrm{mV} / \mathrm{s}$ which confirms the irreversibility of the reduction process. The formal redox potential $\left(E_{f}^{0}=\left(E_{p, a}+E_{p, c}\right) / 2\right)$ for the above mention process can be taken as $-0.795 \mathrm{~V}$. The oxidation potential $\left(E_{p, a}\right)_{b}=+0.420 \mathrm{~V}$ provides the electron donating energy level of the test dye in its ground state with respect to reference electrode.

3.3.3. Optical Properties of Nickel Xylenol Complex. Since the optical property of a compound, to be used as a sensitizer, plays the significant role in mediating the photoelectrochemical process at the semiconductor electrode (photosensitization) in a photoelectrochemical cell, the absorption 


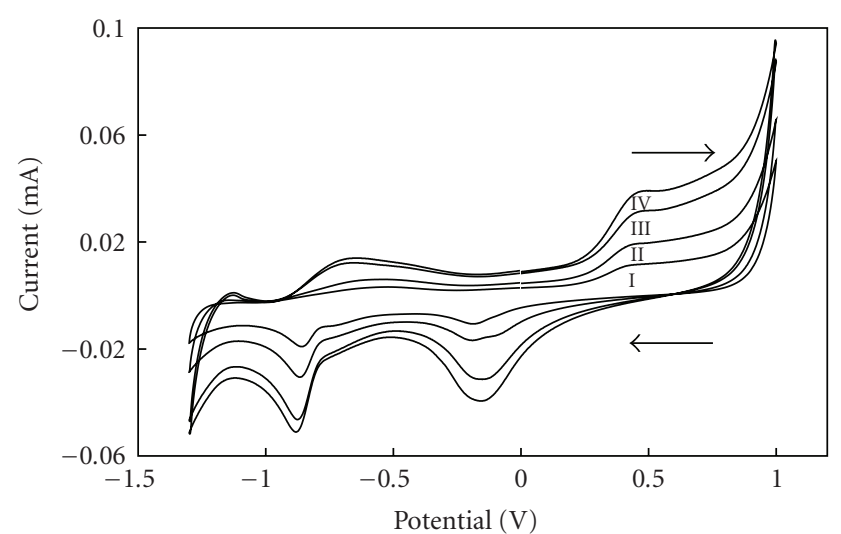

(a)

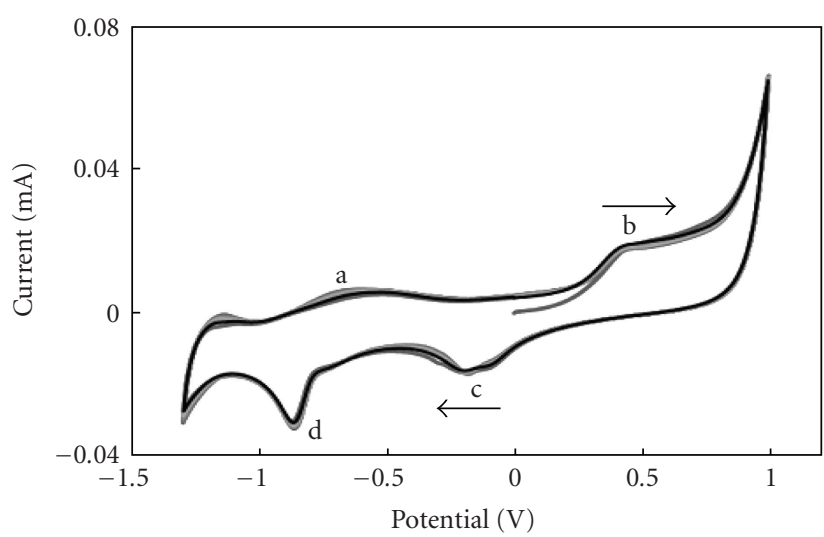

(b)

Figure 3: (a) Cyclic voltammogram in aqueous medium containing $0.1 \mathrm{mM}$ test dye $+0.1 \mathrm{M} \mathrm{NaClO}_{4}$ supporting electrolyte at different scan rates I-20, II-50, III-60, and IV-100 mV/s. (b) Cyclic voltammogram in aqueous medium containing $0.1 \mathrm{mM}$ test dye $+0.1 \mathrm{M}$ $\mathrm{NaClO}_{4}$ supporting electrolyte at scan rate of $100 \mathrm{mV} / \mathrm{s}$ (10 cycles).

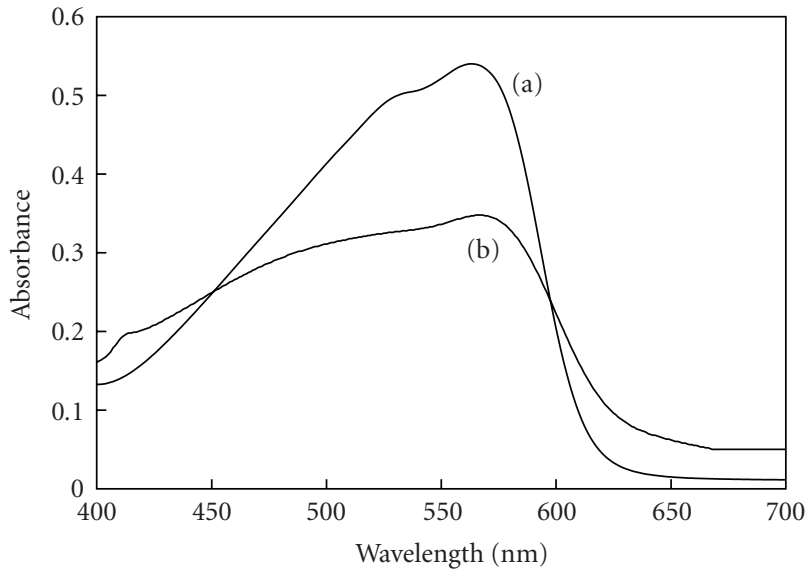

Figure 4: Absorption spectra of (a) aqueous solution of $\mathrm{Ni}$ (II) xylenol complex $(0.1 \mathrm{mM})$ and (b) $\mathrm{ZnO} / \mathrm{Ni}$ (II) xylenol complex thin film electrode.

spectrum of the test dye of $0.1 \mathrm{mM}$ concentration in aqueous medium was determined and the same is shown in Figure 4(a). This figure shows clearly that the dye can absorb visible light in the range of 400-620 nm wavelengths with characteristic absorption peak at $563 \mathrm{~nm}$. With this sensitizer it seems possible to extend the spectral response of the $\mathrm{ZnO}$ electrodes well into the visible region of the solar spectrum (up to $\sim 620 \mathrm{~nm}$ wavelength). Thus, this compound absorbs light of appropriate wavelength and can be used as photosensitizer for wide-band gap semiconductors such as $\mathrm{ZnO}$ $\left(E_{g}=3.48 \mathrm{eV}\right)$ which alone cannot absorb visible light. Figure 4(b) shows the absorption spectrum of $\mathrm{Ni}$ (II)-xylenol complex dye coated- $\mathrm{ZnO}$ thin-film electrode.

3.3.4. Energy Level Diagram. In order to study that the photo induced electron injection by dye molecules into the conduction band of $\mathrm{ZnO}$ electrode and the dye regeneration processes are thermodynamically feasible or not, an energy level diagram has been constructed on electrochemical scale. The flat band potential of the $\mathrm{ZnO}$ electrode $(-506 \mathrm{mV})$ has been obtained from the current-potential plot (discussed later) which provided the position of the Fermi level at the surface of the semiconductor electrode under flat band condition. Assuming the conduction band edge at $0.1 \mathrm{eV}$ above the Fermi level, we get $E_{\mathrm{CB}}=-606 \mathrm{mV}$. Since $E_{g}=3.48 \mathrm{eV}$ for nanocrystalline $\mathrm{ZnO}$, the upper edge of the valence band was taken at $+2.874 \mathrm{~V}$. Further, the oxidation potential of the dye $\left(E_{\mathrm{D} / \mathrm{D}^{+}}^{0}=+0.420 \mathrm{~V}\right)$ determined from the cyclic voltammetry provided the electron donating energy level of the dye molecules in their ground state (D) (Figure 5). This coupled with the excitation energy of the dye $(2.2 \mathrm{eV}$ corresponding to $\lambda_{\max }=563 \mathrm{~nm}$ ) provided the electrondonating energy level of the excited dye molecules $\left(D^{*}\right)$ as $E_{\mathrm{D}^{*} / \mathrm{D}^{+}}^{0}=-1.78 \mathrm{~V}$. The redox potential of $\mathrm{I}^{-} / \mathrm{I}_{3}{ }^{-}(0.5 \mathrm{~V})$ was taken from the literature. The energy level diagram clearly demonstrates that both the processes, (i) electron injection by photoexcited dye molecules into the conduction band of the semiconductor and (ii) regeneration of dye $\left(\mathrm{D}^{+}+\mathrm{e}^{-} \rightarrow \mathrm{D}\right)$ are thermodynamically feasible. To examine the kinetic aspects of the photo-induced electron transfer processes in terms of obtainable dye-sensitized photocurrent, the following experiments were performed.

3.3.5. Current-Potential Characteristics. In order to assess the sensitizing ability of the dye, current-potential $(J-V)$ curves were determined using dye-coated $\mathrm{ZnO}$ thin film as photoanode and Pt (screen-printed) as counter electrode in a sandwich type cell having $\mathrm{I}^{-} / \mathrm{I}_{3}{ }^{-}$redox couple in the cell electrolyte. The current-potential characteristics recorded under visible and white light illumination are shown in Figure 6. Open circuit cell voltage $V_{\mathrm{oc}}=506 \mathrm{mV}$ and short circuit photocurrent $J_{\mathrm{sc}}=1.68 \mathrm{~mA} / \mathrm{cm}^{2}$ were observed under white light (Figure 6(a)) and open circuit cell voltage $V_{\mathrm{oc}}=506 \mathrm{mV}$ and short circuit photocurrent $J_{\mathrm{sc}}=$ $1.4 \mathrm{~mA} / \mathrm{cm}^{2}$ were observed under visible light (Figure 6(b)). Actual illuminated area of the working electrode was 


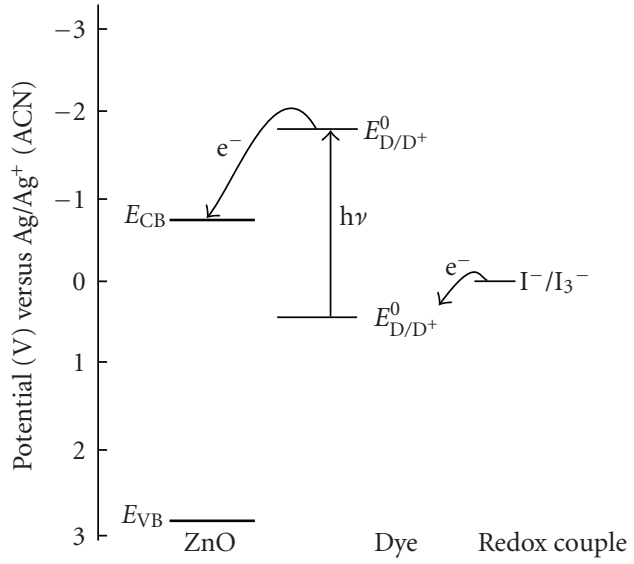

FIGURE 5: Schematic energy level diagram for injection of electrons from an adsorbed dye molecule in excited state $\left(D^{*}\right)$ to the conduction band of $\mathrm{ZnO}$ and a subsequent regeneration of the dye.

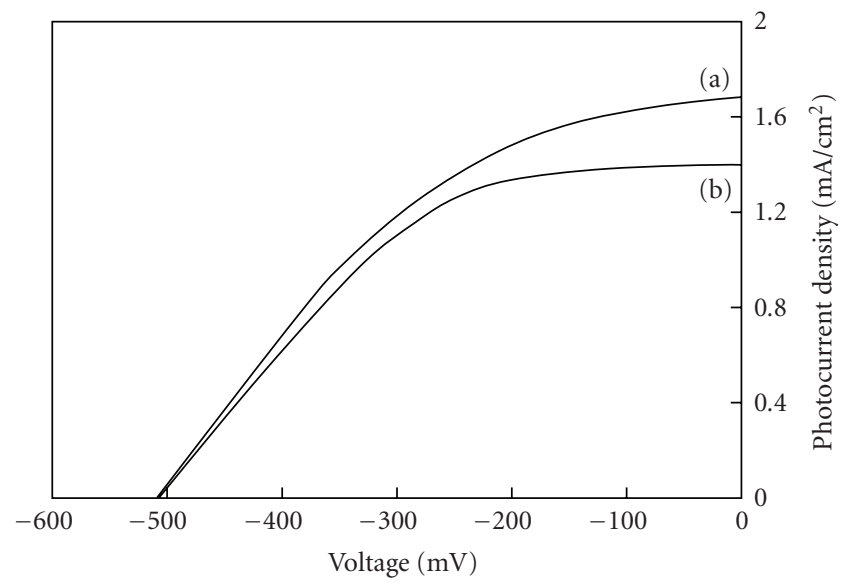

FIgURE 6: $J-V$ characteristics of the dye-sensitized solar cell (nanocrystalline dye-coated $\mathrm{ZnO}$ thin film/electrolyte/Pt counter electrode) under illumination with (a) white light $\left(520 \mathrm{~mW} / \mathrm{cm}^{2}\right)$ and (b) visible light $\left(480 \mathrm{~mW} / \mathrm{cm}^{2}\right)$. Illuminated area $=0.23 \mathrm{~cm}^{2}$.

$0.23 \mathrm{~cm}^{2}$. From these curves, it is evident that photocurrent onset occurs at around $0.506 \mathrm{~V}$, and hence it can be taken as the flat band potential $\left(V_{\mathrm{fb}}\right)$ of the $\mathrm{ZnO}$ electrode in the experimental solution. This value of $V_{\mathrm{fb}}$ has been used in constructing the energy level diagram (Figure 5).

3.3.6. Dependence of Photocurrent on Intensity of Light. Keeping the semiconductor electrode under at short circuit condition, it was illuminated with white light of different intensities using neutral density filters and the responded currents were measured and the results are shown in Figure 7. The linear variation in photocurrent with the intensity of light shows that the recombination of dye-injected charge carriers is almost negligible in this case.

3.3.7. Transient Photocurrent Response. The transient current-time profiles were recorded to know the sustainability of the photocurrent observed initially on illumination of

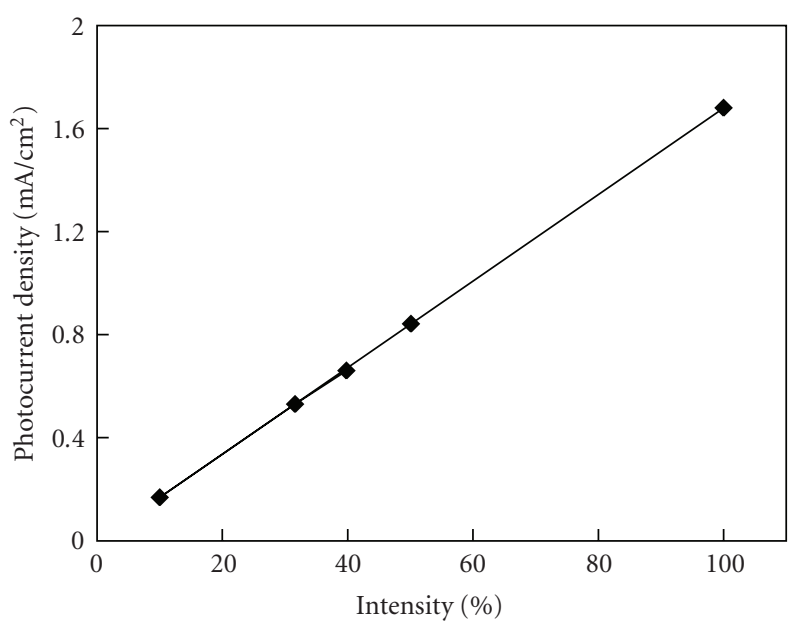

FIGURE 7: Short circuit photocurrent as a function of intensity of light for nanocrystalline $\mathrm{ZnO} /$ dye-sensitized solar cell.

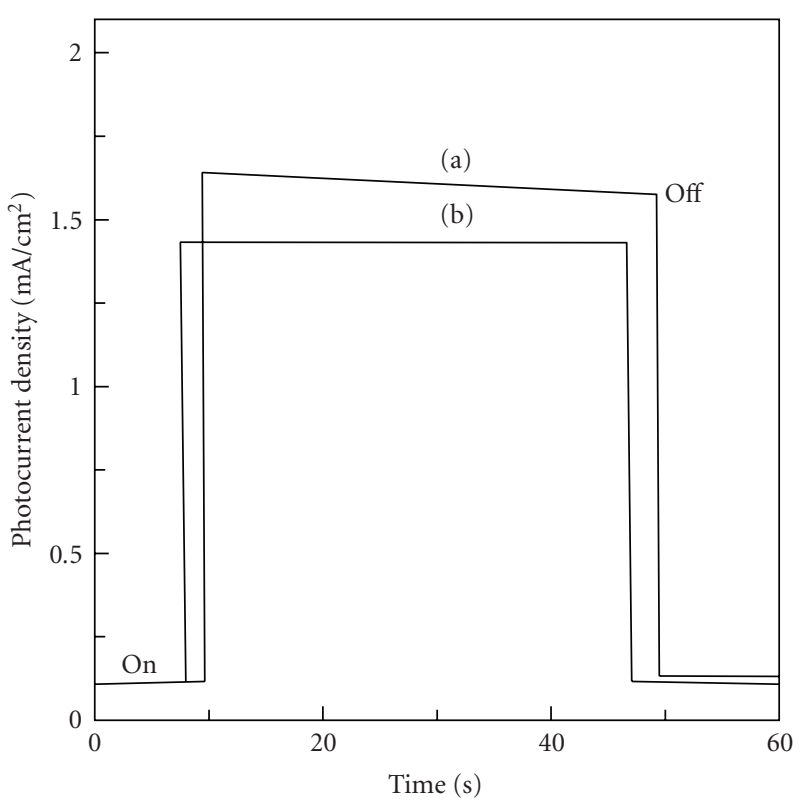

Figure 8: Transient current-time $(J-t)$ curves for nanocrystalline $\mathrm{ZnO} /$ dye-sensitized solar cell under short circuit condition and illumination with (a) white light and (b) visible light.

the semiconductor electrode. For such an assessment, the time dependent response of dye-sensitized $\mathrm{ZnO}$ electrode to light was determined in terms of short circuit photocurrent and the results are shown in Figure 8. These photocurrent-time $\left(J_{\text {photo }}-t\right)$ profiles were obtained under illumination of the semiconductor electrode with white light (curve a) and visible light (curve b). Under white light illumination, the photocurrent attained initially was not sustained subsequently and it decayed to $95 \%$ of its initial value before getting stabilized (curve a). But under visible light illumination, no such decay in photocurrent was observed (curve b). The observed decay in photocurrent in the first case (curve a) is probably due to high intensity of 


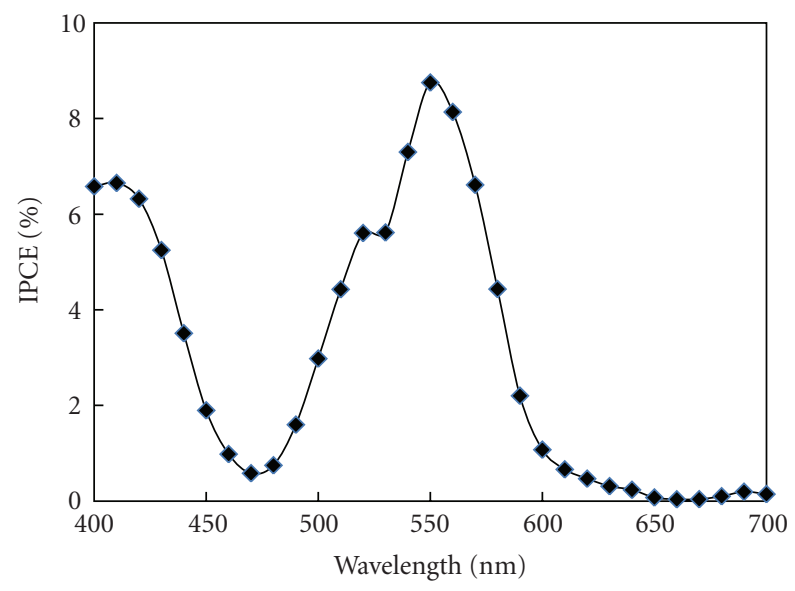

FIgUre 9: The IPCE as a function of the wavelength of incident monochromatic lightfor sandwich type nanocrystalline $\mathrm{ZnO}$-dyesensitized solar cell.

the white light, which makes the loss due to charge carriers' recombination more significant. This may also be the result of slowness of dye regeneration process as compared to charger carriers' injection by excited dye molecules.

\subsubsection{Incident Photon-to-Current Conversion Efficiency} (IPCE). Incident photon-to-current conversion efficiency (IPCE) was evaluated for each wavelength of monochromatic light. From the value of short circuit photocurrent $J_{\mathrm{sc}}$ and the intensity of the corresponding monochromatic light $\left(I_{\text {inc }}\right)$, the incident photon-to-current conversion efficiency (IPCE) was calculated at each excitation wavelength $(\lambda)$ using the following relation:

$$
\operatorname{IPCE}(\%)=\frac{\left.1240 J_{\mathrm{sc}}(\mathrm{mA} \mathrm{cm})^{-2}\right)}{\lambda(\mathrm{nm}) \times I_{\mathrm{inc}}\left(\mathrm{Wcm}^{-2}\right)} \times 100 .
$$

Maximum IPCE for the present system was found to be $8.7 \%$ (Figure 9) at wavelength $\left(\lambda_{\max }=563 \mathrm{~nm}\right)$ which is comparable to that reported for recently synthesized ruthenium metal complex by Funaki et al. [33]. The decrease in IPCE towards the longer wavelength region (above $563 \mathrm{~nm}$ ) ws ascribed to the decrease of light harvesting by the dye.

3.3.9. Evaluation of Fill Factor (FF). For the determination of fill factor of the cell, current was recorded as a faction of cell voltage keeping the sandwich cell illuminated with desired light. The maximum power $P_{\max }$ was determined from current-potential curve by choosing a point on the curve corresponding to which the product of the current $J_{\max }$ and potential $V_{\max }$ gives the maximum value. The fill factor (FF) was then calculated by using the equation

$$
\mathrm{FF}=\frac{J_{\max } \times V_{\mathrm{max}}}{J_{\mathrm{sc}} \times V_{\mathrm{oc}}},
$$

where $I_{\text {inc }}$ is the power of incident light $\left(520 \mathrm{~mW} / \mathrm{cm}^{2}\right.$ for white light and $480 \mathrm{~mW} / \mathrm{cm}^{2}$ in visible light), $V_{\text {oc }}$ the opencircuit photovoltage and $J_{\mathrm{sc}}$ the short-circuit photocurrent.
It was seen that DSSCs with this $\mathrm{ZnO}$ thin film achieved short circuit current $\left(J_{\mathrm{sc}}\right)$ of $1.68 \mathrm{~mA} / \mathrm{cm}^{2}$, open circuit voltage of $506 \mathrm{mV}$, and a fill factor of $41 \%$ under white light and short circuit current $\left(J_{\mathrm{sc}}\right)$ of $1.4 \mathrm{~mA} / \mathrm{cm}^{2}$, open circuit voltage of $506 \mathrm{mV}$, and a fill factor of $49 \%$ under visible light illumination conditions.

Based on the findings of these investigations it can be concluded that xylenol $\mathrm{Ni}$ (II) metal complex can extend the spectral response of high band-gap semiconductor electrodes to visible light (up to about $600 \mathrm{~nm}$ wavelength). The dye used in this study was unable to harvest the majority of the energy from the solar spectrum since this dye has significant light absorption only up to $\sim 600 \mathrm{~nm}$. It is due to the formation of aggregates as well as lack of harvesting ability in the longer wavelength region, that is, poor overlapping of the radiation spectrum of light source (here xenon lamp) and the absorption spectrum of the dye. Efficiency can possibly be improved on optimization of various components such as by using catalyst-coated counter electrode, kinetically more efficient redox couple, sensitizing other metal semiconducting thin films (i.e., $\mathrm{TiO}_{2}, \mathrm{CdS}$, etc.), and so on. Another possible way of improving the performance is to use appropriate metal ion, other than Nickel (II), with proper energy levels reacting with (3,30-bis[N,Ndi(carboxymethyl)aminomethyl]-o-cresolsulfonephthalein) ligand which can have absorption bands at larger wavelengths [34]. Efforts in this direction are underway.

\section{Conclusion}

A new transition metal complex has been studied for its photosensitizing properties by using it in dye-sensitized solar cell. Based on the findings of the present investigations, it can be concluded that Ni(II) xylenol metal complex acts as a donor-type sensitizer, and it is capable of extending the spectral response of $\mathrm{ZnO}$ electrode up to $\sim 600 \mathrm{~nm}$ wavelength of visible light. The absorption spectrum of aqueous solution of this complex exhibits a strong peak at $563 \mathrm{~nm}$ and a shoulder at $526 \mathrm{~nm}$ wavelength of light. The sandwichtype dye-sensitized solar cell using $\mathrm{ZnO}$ semiconducting thin film with test dye anchored onto it showed the cell output as follows: $V_{\mathrm{oc}}=0.506 \mathrm{~V}, J_{\mathrm{sc}}=1.68 \mathrm{~mA} \mathrm{~cm}^{-2}$, and $\mathrm{FF}=0.41$ under illumination with full spectrum of light (intensity $=520 \mathrm{~mW} \mathrm{~cm}^{-2}$ ) while on illumination with visible light $\left(\lambda>420 \mathrm{~nm}\right.$, intensity $\left.480 \mathrm{~mW} \mathrm{~cm}^{-2}\right) V_{\mathrm{oc}}=$ $0.506 \mathrm{~V}, J_{\mathrm{sc}}=1.4 \mathrm{~mA} \mathrm{~cm}^{-2}$, and $\mathrm{FF}=0.49$ were achieved. Maximum incident photon-to-current conversion efficiency for the present system was found to be $8.7 \%$ at wavelength $\left(\lambda_{\max }=563 \mathrm{~nm}\right)$.

\section{Acknowledgments}

Financial support from the Ministry of New and Renewable Energy (MNRE) and University Grant Commission, New Delhi, to S. Kushwaha is gratefully acknowledged. Author (S. Kushwaha) is also thankful to Metallurgical and Ceramic Engineering Departments of the Institute of Technology, Banaras Hindu University for providing the SEM and XRD facilities. 


\section{References}

[1] M. Grätzel, "Photoelectrochemical cells," Nature, vol. 414, no. 6861, pp. 338-344, 2001.

[2] A. Hagfeldt and M. Grätzel, "Molecular photovoltaics," Accounts of Chemical Research, vol. 33, no. 5, pp. 269-277, 2000.

[3] M. K. Nazeeruddin, A. Kay, I. Rodicio et al., "Conversion of light to electricity by cis-Xbis (2,2'-bipyridyl-4,4'dicarboxylate)ruthenium(II) charge-transfer sensitizers ( $\mathrm{X}=$ $\mathrm{Cl}, \mathrm{Br}, \mathrm{I}, \mathrm{CN}$, and $\mathrm{SCN}$ ) on nanocrystalline TiO electrodes," Journal of the American Chemical Society, vol. 115, no. 14, pp. 6382-6390, 1993.

[4] J. Chen, J. Wu, W. Lei, J. L. Song, W. Q. Deng, and X. W. Sun, "Co-sensitized quantum dot solar cell based on $\mathrm{ZnO}$ nanowire," Applied Surface Science, vol. 256, no. 24, pp. 74387441, 2010.

[5] J. B. Baxter and E. S. Aydil, "Dye-sensitized solar cells based on semiconductor morphologies with $\mathrm{ZnO}$ nanowires," Solar Energy Materials and Solar Cells, vol. 90, no. 5, pp. 607-622, 2006.

[6] K. Keis, E. Magnusson, H. Lindström, S. E. Lindquist, and A. Hagfeldt, "A 5\% efficient photoelectrochemical solar cell based on nanostructured $\mathrm{ZnO}$ electrodes," Solar Energy Materials and Solar Cells, vol. 73, no. 1, pp. 51-58, 2002.

[7] B. Pradhan, S. K. Batabyal, and A. J. Pal, "Vertically aligned $\mathrm{ZnO}$ nanowire arrays in Rose Bengal-based dye-sensitized solar cells," Solar Energy Materials and Solar Cells, vol. 91, no. 9, pp. 769-773, 2007.

[8] L. Lu, R. Li, K. Fan, and T. Peng, "Effects of annealing conditions on thephotoelectrochemical properties of dyesensitized solar cells made with $\mathrm{ZnO}$ nanoparticles," Solar Energy, vol. 84, no. 5, pp. 844-853, 2010.

[9] L. C. Damonte, V. Donderis, S. Ferrari, M. Meyer, J. Orozco, and M. A. Hernández-Fenollosa, "ZnO-based nanocrystalline powders with applications in hybrid photovoltaic cells," International Journal of Hydrogen Energy, vol. 35, no. 11, pp. 5834-5837, 2010.

[10] B. O’Regan and M. Grätzel, "A low-cost, high-efficiency solar cell based on dye-sensitized colloidal $\mathrm{TiO}_{2}$ films," Nature, vol. 353, no. 6346, pp. 737-740, 1991.

[11] K. Kalyanasundaram and M. Grätzel, "Applications of functionalized transition metal complexes in photonic and optoelectronic devices," Coordination Chemistry Reviews, vol. 177, no. 1, pp. 347-414, 1998.

[12] A. S. Polo, M. K. Itokazu, and N. Y. Murakami Iha, "Metal complex sensitizers in dye-sensitized solar cells," Coordination Chemistry Reviews, vol. 248, no. 13-14, pp. 1343-1361, 2004.

[13] M. Grätzel, "Solar energy conversion by dye-sensitized photovoltaic cells," Inorganic Chemistry, vol. 44, no. 20, pp. 68416851, 2005.

[14] A. S. Polo, M. K. Itokazu, and N. Y. Murakami Iha, "Metal complex sensitizers in dye-sensitized solar cells," Coordination Chemistry Reviews, vol. 248, no. 13-14, pp. 1343-1361, 2004.

[15] R. Argazzi, N. Y. Murakami Iha, H. Zabri, F. Odobel, and C. A. Bignozzi, "Design of molecular dyes for application in photoelectrochemical and electrochromic devices based on nanocrystalline metal oxide semiconductors," Coordination Chemistry Reviews, vol. 248, no. 13-14, pp. 1299-1316, 2004.

[16] H. Choi, J. K. Lee, K. Song, S. O. Kang, and J. Ko, "Novel organic dyes containing bis-dimethylfluorenyl amino benzo[b]thiophene for highly efficient dye-sensitized solar cell," Tetrahedron, vol. 63, no. 15, pp. 3115-3121, 2007.
[17] X. Gan, X. Li, X. Gao, X. He, and F. Zhuge, "Deposition potential dependence of $\mathrm{ZnO}$-eosin $\mathrm{Y}$ hybrid thin films prepared by electrochemical deposition and their photoelectrochemical properties," Materials Chemistry and Physics, vol. 114, no. 2-3, pp. 920-925, 2009.

[18] K. Hara, M. Kurashige, Y. Dan-Oh et al., "Design of new coumarin dyes having thiophene moieties for highly efficient organic-dye-sensitized solar cells," New Journal of Chemistry, vol. 27, no. 5, pp. 783-785, 2003.

[19] W. P. Tai and K. Inoue, "Eosin Y-sensitized nanostructured SnO/TiO solar cells," Materials Letters, vol. 57, no. 9-10, pp. 1508-1513, 2003.

[20] R. Chen, X. Yang, H. Tian, X. Wang, A. Hagfeldt, and L. Sun, "Effect of tetrahydroquinoline dyes structure on the performance of organic dye-sensitized solar cells," Chemistry of Materials, vol. 19, pp. 4507-4017, 2007.

[21] L. Bahadur and J. P. Pandey, "Spectral sensitization of sprayed thin film $\mathrm{n}-\mathrm{ZnO}$ electrodes by 4-p-dimethylaminobenzylidene-1,2-diphenyl-2-imidazoline-5-one in acetonitrile solution," Journal of Applied Electrochemistry, vol. 22, no. 9, pp. 883-887, 1992.

[22] L. Bahadur and J. P. Pandey, "Photosensitization of thin film n- $\mathrm{ZnO}$ electrode by an oxo-uranium (VI) complex in non-aqueous (acetonitrile) photoelectrochemical cell," Indian Journal of Chemistry A, vol. 32, pp. 285-288, 1993.

[23] L. Bahadur, J. P. Pandey, and T. N. Rao, "Photoelectrochemistry of $\mathrm{ZnO}$ thin film electrode sensitized by an oxouranium (VI) complex in an acetonitrile photocell," Proceedings of the Indian Academy of Sciences-Chemical Sciences, vol. 105, no. 4-5, pp. 235-243, 1993.

[24] L. Bahadur and J. P. Pandey, "Photoelectrochemical studies of sprayed thin film $\mathrm{ZnO} /$ acetonitrile based photocell sensitized by rhodamine B," Indian Journal of Chemical Technology, vol. 1, pp. 53-59, 1994.

[25] L. Bahadur and L. Roy, "Spectral sensitization of a sprayed $\mathrm{ZnO}$ thin film electrode by a new synthetic dye (2-imidazolin5-one) in acetonitrile medium," Semiconductor Science and Technology, vol. 10, no. 3, pp. 358-364, 1995.

[26] L. Bahadur and P. Srivastava, "Efficient photon-to-electron conversion with rhodamine 6G-sensitized nanocrystalline n$\mathrm{ZnO}$ thin film electrodes in acetonitrile solution," Solar Energy Materials and Solar Cells, vol. 79, no. 2, pp. 235-248, 2003.

[27] L. Bahadur and J. P. Pandey, "Voltammetric studies of some oxo-uranium (VI) complexes of dithio ligands at thin film semiconducting $\mathrm{ZnO} /$ acetonitrile interface for photosensitizer applications," Journal of the Electrochemical Society, vol. 137, no. 12, pp. 3755-3760, 1990.

[28] G. Pandey and K. K. Narang, "Synthesis, characterization, spectral studies and antifungal activity of $\mathrm{Mn}(\mathrm{II}), \mathrm{Fe}(\mathrm{II})$, $\mathrm{Co}(\mathrm{II}), \mathrm{Ni}(\mathrm{II}), \mathrm{Cu}(\mathrm{II})$ and $\mathrm{Zn}(\mathrm{II})$ complexes with 3,3'bis[N,N,di(carboxymethyl)-aminomethyl]-o-cresol sulphonphthalein," Journal of Coordination Chemistry, vol. 59, no. 13, pp. 1495-1507, 2006.

[29] A. I. Vogel, Textbook of Practical Organic Chemistry, ELBS Publications, 4th edition, 1978.

[30] L. Spanhel and M. A. Anderson, "Semiconductor clusters in the sol-gel process: quantized aggregation, gelation, and crystal growth in concentrated $\mathrm{ZnO}$ colloids," Journal of the American Chemical Society, vol. 113, no. 8, pp. 2826-2833, 1991.

[31] M. K. Jayaraj, A. Antony, and M. Ramachandran, "Transparent conducting zinc oxide thin film prepared by off-axis $\mathrm{rf}$ magnetron sputtering," Bulletin of Materials Science, vol. 25, no. 3, pp. 227-236, 2002. 
[32] İ. Bulut, "Study of binary complexes of nickel(II), copper(II), and vanadium $(\mathrm{V})$ with acetazolamide in aqueous medium by voltammetry," Turkish Journal of Chemistry, vol. 33, pp. 1-3, 2009.

[33] T. Funaki, M. Yanagida, N. Onozawa-Komatsuzaki et al., "Synthesis of a new class of cyclometallated ruthenium(II) complexes and their application in dye-sensitized solar cells," Inorganic Chemistry Communications, vol. 12, pp. 842-845, 2009.

[34] T. Matsubara, Y. Ichikawa, K. Aramaki, and A. Katagiri, "The use of xylenol orange in a dye-sensitized solar cell," Solar Energy Materials and Solar Cells, vol. 85, no. 2, pp. 269-275, 2005. 


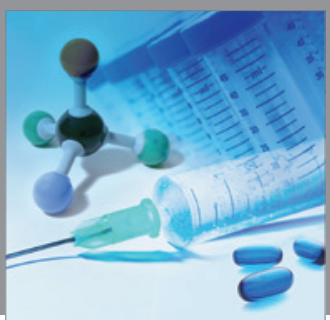

International Journal of

Medicinal Chemistry

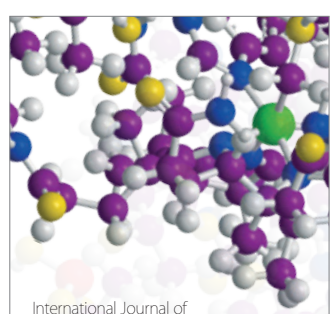

Carbohydrate Chemistry

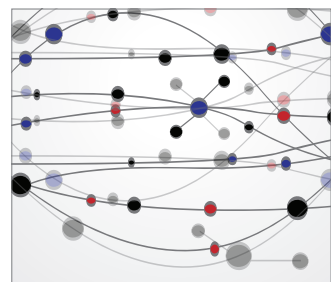

The Scientific World Journal
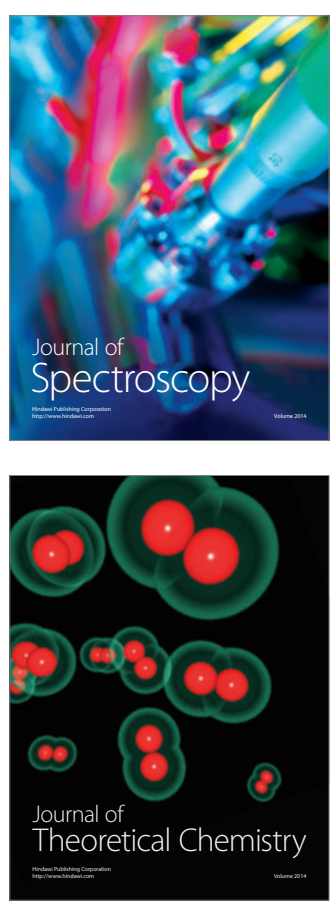
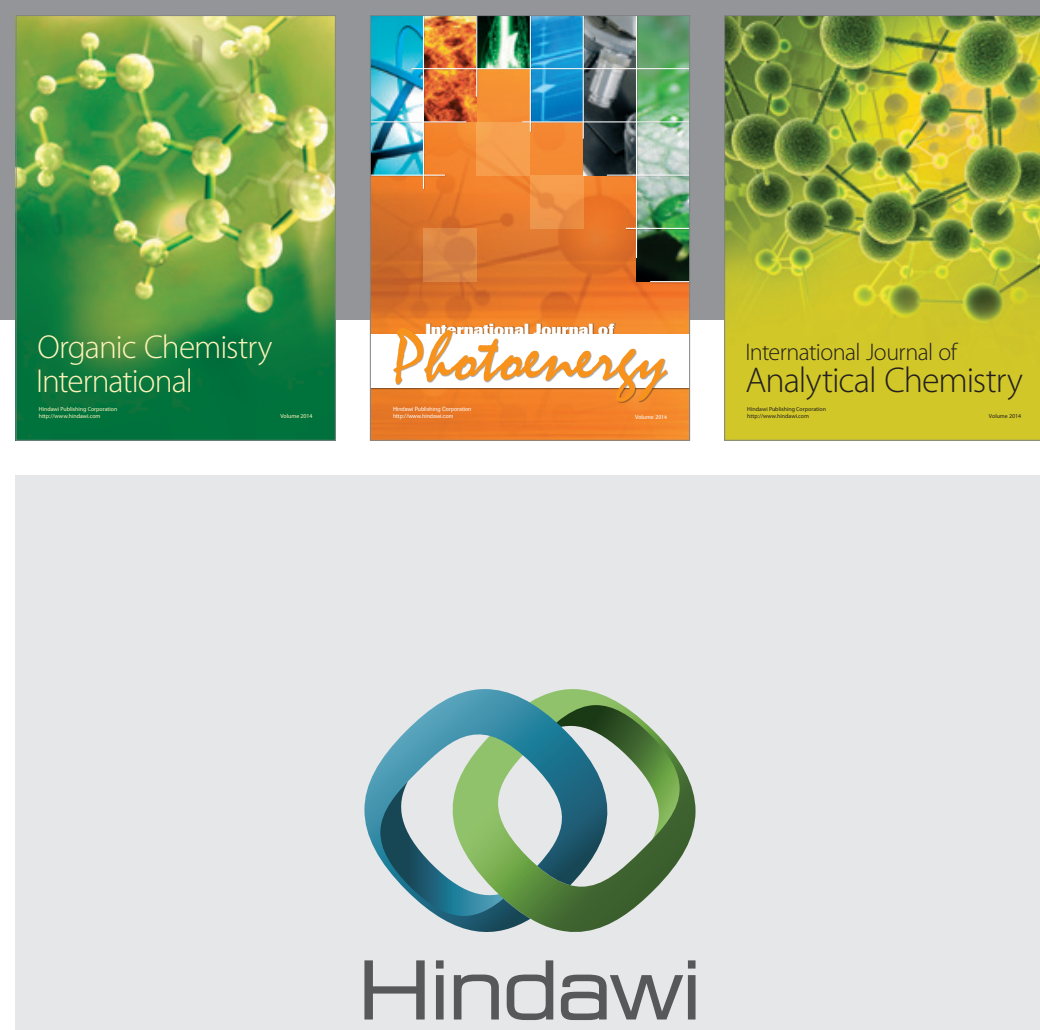

Submit your manuscripts at

http://www.hindawi.com
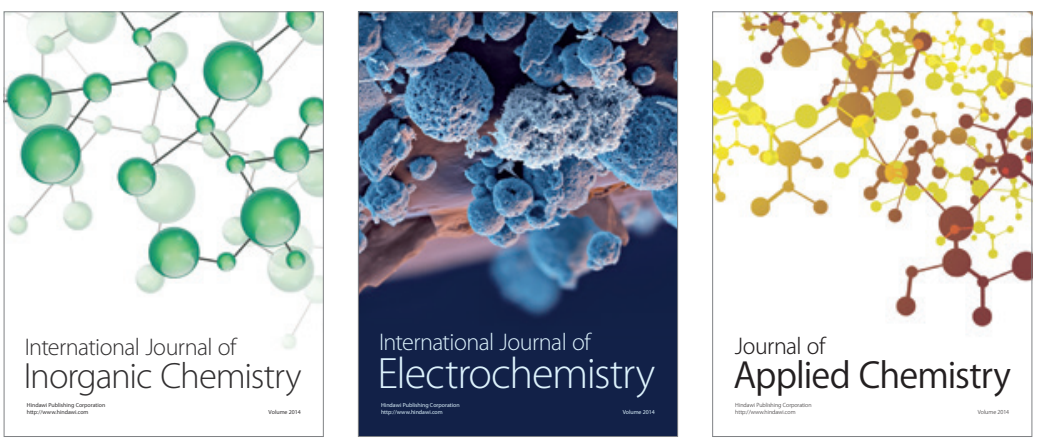

Journal of

Applied Chemistry
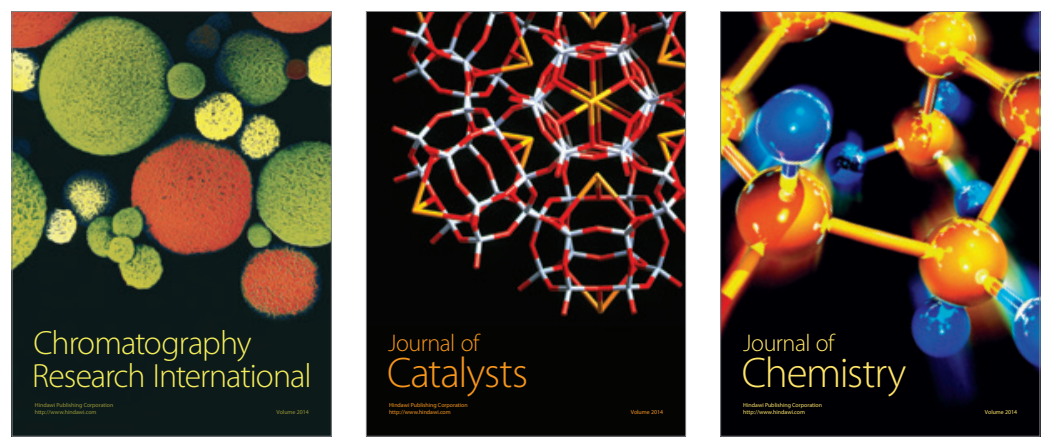
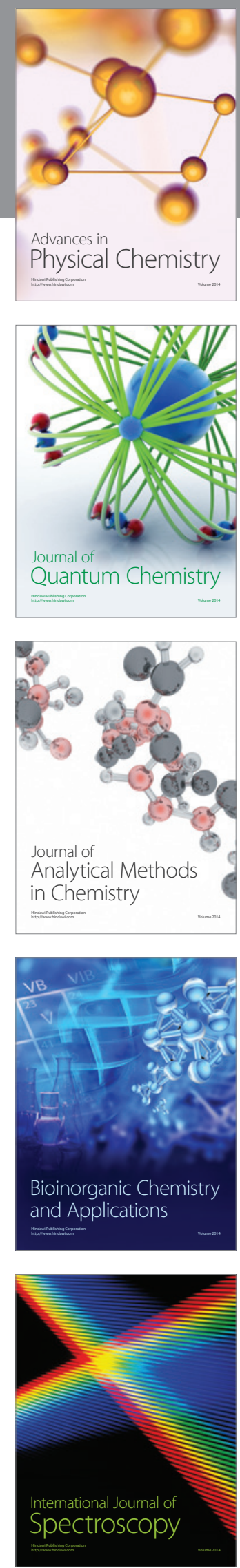